\title{
GAMBARAN KESIAPAN MENARCHE SISWI DI SD 2 DALUNG
}

\author{
Ida Arimurti Sanjiwani' ${ }^{1}$ I Gusti Ayu Pramitaresthi ${ }^{1}$ \\ ${ }^{1}$ Dosen Program Studi Sarjana Keperawatan dan Profesi Ners Fakultas Kedokteran Universitas Udayana \\ Alamat Korespondensi : ida.arimurti@unud.ac.id
}

\begin{abstract}
Abstrak
Peralihan dari masa kanak-kanak ke masa remaja akan mengalami pubertas yang ditandai dengan terjadinya kematangan seksual dan perubahan fisik dan menarhce. Kesiapan menghadapi menarche berdampak terhadap reaksi remaja putri saat datangnya menstruasi yang pertama. Penelitian ini bertujuan untuk mengetahui tingkat kesiapan siswi dalam menjalani menarche. Penelitian ini merupakan penelitian deskriptif kuantitatif dengan pendekatan observasional. Penelitian ini menggunakan teknik stratified random sampling pada 65 siswi di SD 2 Dalung. Data diperoleh dengan kuesioner kesiapan menarche dengan hasil menunjukkan bahwa tingkat kesiapan siswi dalam menghadapi menache yaitu pada katagori kurang $(5,34)$. Disarankan untuk dapat dilakukan pendekatan dan edukasi baik dari keluarga dan sekolah untuk meningkatkan kesiapan siswi dalam menghadapi menarche.
\end{abstract}

Kata Kunci: Kesiapan, Menarche, siswi

\begin{abstract}
The transition from childhood to adolescence will experience puberty which is characterized by sexual maturity and physical changes and menarhce. The readiness to face menarche has an impact on the reactions of young women when their first menstrual period arrives. This study aims to determine the level of readiness of students in undergoing menarche. This research was a quantitative descriptive study with an observational approach. This study used a stratified random sampling technique to 65 female students at SD 2 Dalung. The data were obtained by using a menarche readiness questionnaire with the results showing that the level of readiness of students in facing menache was in the low category $(5,34)$. It is suggested that an approach and education be carried out from both families and schools to improve students' readiness to face menarche.
\end{abstract}

Key words: Readiness, Menarche, Schoolgirl

\section{PENDAHULUAN}

Remaja adalah fase peralihan
individu pada usia $10-19$ tahun (UNICEF,2011). Tahap remaja ini ditandai oleh adanya kematangan seksual, perubahan fisik, dan terjadinya menarche pada remaja putri. Menarche adalah suatu tanda yang penting bagi seseorang wanita yang menunjukkan adanya produksi hormon yang disekresikan oleh hipotalamus dan kemudian diteruskan pada ovarium dan uterus (Sukarni \& Wahyu, 2013). WHO menyatakan umur 10-19 tahun sudah mengalami menarche (Efendi \& Makhfudli, 2009). Rentang usia remaja mengalami menarche di berbagai wilayah Asia hampir serupa, seperti di Cina 12,6 tahun dan Korea 12,7 tahun (Lee, et al, 2016). Di Indonesia kisaran usia menarche yaitu antara 12 sampai 14 tahun dengan ratarata usia menurut Riskesdas 2010 adalah 13 tahun dengan kejadian lebih awal pada usia kurang dari sembilan tahun (Batubara, 2010; Badan Penelitian \& Pengembangan Kesehatankementerian Kesehatan RI,2010). Kesiapan menghadapi menarche dapat diartikan suatu keadaan yang menunjukkan bahwa seorang anak perempuan siap untuk mencapai salah satu kematangan fisik yaitu datangnya menstruasi pertama dan memberikan respon melalui cara tertentu (Yusuf, 2002; Azwar,2007). . Kesiapan mental sangat diperlukan sebelum menarche karena perasaan cemas dan takut akan muncul, selain itu juga kurangnya pengetahuan tentang perawatan diri yang diperlukan saat 
menstruasi (Wiknjosastro, 2007). Kesiapan menghadapi menarche berdampak terhadap reaksi remaja putri saat datangnya menstruasi yang pertama (Zahroh, 2006). Remaja yang tidak siap menghadapi menarche akan merasa tidak percaya diri, respon negatif terhadap menarche yang dialaminya seperti merasa takut, terkejut, sedih, kecewa, malu, khawatir, dan bingung (Fajri \& Khairani, 2010). Penelitian sebelumnya mengatakan bahwa sebagian siswi yang mengalami menarke tidak masuk sekolah dan beberapa dilaporkan bolos jam pelajaran karena malu jika terdapat noda darah di baju dan takut diejek oleh teman laki-laki (Behera et al., 2015).

Pengetahuan adalah faktor yang memegang peranan penting dalam menentukan sikap untuk menerima/melakukan sesuatu (Fitriani, 2011). Edukasi mengenai topik menstruasi dapat mempengaruhi persepsi remaja mengenai menarke (Nagar \& Aimol, 2010). Pengetahuan yang kurang terkait menstruasi merupakan salah satu faktor penyebab ketakutan dan ketidaksiapan dalam menghadapi menstruasi dan bisa membuat seseorang sulit menghadapi menarke (Aprilani, 2017). Peran perawat khusnya perawat maternitas secara mandiri yang dapat dikembangkan pada penelitian ini dalam upaya mempersiapkan remaja memasuki menarche yaitu melalui pemberian pendidikan kesehatan. Pendidikan kesehatan bersifat promotif bertujuan meningkatkan kemampuan individu atau kelompok (Notoatmodjo, 2010).

Studi pendahuluan di SD N 2 Dalung yang terletak di Kuta Utara diketahui bahwa siswi di sekolah tersebut siswi SD di kelas enam sudah banyak yang mengalami mentruasi dan di kelas empat dan lima juga sudah mulai ada yang menarche. Terdapat kasus siswi yang menstruasi di sekolah yang ditertawai oleh siswa laki-kali, dan terkadang siswi ijin pulang ke rumah saat menstruasi. Pihak Sekolah juga mengatakan jika siswi mereka jarang membahas mengenai mentsruasi dengan guru di sekolah karena menggap ini hal yang tabu dan malu. Pelaksanaan pendidikan khusus tentang menstruasi jarang dilakukan namun telah disampaikan melakui kegiatan biologi dan olah raga. Oleh karena itu, penulis tertarik untuk mengetahui tentang bagaimanakah gambaran kesiapan siswi dalam menghadapi menarche di SD 2 Dalung.

\section{METODE}

Penelitian ini adalah penelitian deskriptif kuantitatif dengan dengan pendekatan observasional. Penelitian ini menggunakan teknik stratified random sampling pada 65 siswi di SD 2 Dalung. Kriteria inklusi yaitu siswi kelas IV,V, VI dan belum mengalami menarche.

Data dikumpulkan dengan menggunakan kuesioner kesiapan menarche yang telah baku dan sudah pernah digunakan pada penelitian sebelumnya dengan nilai validitas 0,73 dan reabilitas 0,77 . Penilaian jika jawaban benar bernilai 100 untuk 10 item pernyataan. Bila dikatagorikan skor baik bila benar 76-100\% (7,6-10), cukup bila 56-75\% (5,6-7), kurang bila $<55 \%$ ( $<$ $5,5)$. Pengumpulan data hanya dilakukan satu kali dengan langsung datang ke sekolah dan sebelumnya telah dijelaskan tentang penelitian dan informed consent diisi oleh orang tua/wali kelas. Penelitian ini juga telah melalui kajian etik dari Komisi Etik Penelitian FK Unud/RSUP Sanglah Denpasar. 
HASIL PENELITIAN

Tabel 1. Distribusi Responden Menurut Usia dan Kelas (n-65)

\begin{tabular}{lllllll}
\hline No & Variabel & Frekuensi & Presentase (\%) & Median & Maksimum & Minimum \\
\hline 1 & Usia & & & 11 & 9 & 12 \\
& $9 \mathrm{Th}$ & 17 & $26,2 \%$ & & & \\
& $10 \mathrm{Th}$ & 15 & $32,1 \%$ & & & \\
& $11 \mathrm{Th}$ & 24 & $36,9 \%$ & & & \\
& $12 \mathrm{Th}$ & 9 & $13,8 \%$ & & VI & \\
\hline 2 & Kelas & & & & & \\
& IV & 19 & $29,2 \%$ & & & \\
& V & 20 & $30,8 \%$ & & & \\
& VI & 26 & $40 \%$ & & & \\
& & & & & &
\end{tabular}

Tabel 2. Distribusi Responden Menurut variabel penelitian (n-65)

\begin{tabular}{llllll}
\hline No & Variabel & Frekuensi & Presentase (\%) & Mean & SD \\
\hline 1 & Skor Kesiapan & & & & \\
& 2 & 5 & $7,7 \%$ & & \\
& 3 & 8 & $12,3 \%$ & & \\
& 4 & 10 & $15,4 \%$ & & \\
& 5 & 12 & $18,5 \%$ & 5,34 & \\
& 6 & 11 & $16,9 \%$ & & \\
& 7 & 9 & $13,8 \%$ & & \\
& 8 & 6 & $9,2 \%$ & & \\
& 9 & 4 & $6,2 \%$ & & \\
& & & & & \\
& TOTAL & 65 & $100 \%$ & & \\
\hline
\end{tabular}


Tabel 1 diatas menunjukkan bahwa responden terbanyak berusia 11 Tahun dengan presentase sebesar $36,9 \%$, demikian pula dengan rerata usia responden yaitu 11 tahun. Distribusi karakteristik responden berdasarkan kelas paling banyak pada kelas enam yaitu $40 \%$ dengan rerata kelas $\mathrm{V}$.

Tabel 2 menunjukkan bahwa skor kesiapan siswi menghadapin menarche rata-rata 5,4. Skor terbanyak adalah 6.

\section{PEMBAHASAN}

Karakteristik responden dalam penelitian ini berdasarkan tingkat rerata usia adalah 11 tahun, dengan usia termuda adalah 9 tahun dan yang tertua 12 tahun. Penelitian ini diketahui bahwa tidak ada siswi yang mengalami menarche sebelum usia Sembilan tahun. Data yang dijumpai pada karakteristik usia sejalan dengan teori bahwa umumnya remaja mengalami menarche pada usia 12-16 tahun. Selain itu, berdasarkan Penelitian Kesehatan Dasar tahun 2010, usia rata-rata menarche pada wanita usia 10 hingga 59 tahun di Indonesia adalah 13 tahun dengan usia lebih dini pada usia kurang dari sembilan tahun (Kusmiran, 2011).

Pada penelitian lainnya diketahui bahwa rata-rata anak mengalami menarche lebih awal seperti pada usia 11,9 tahun yang dipengaruhi oleh beberapa faktor seperti status gizi, asupan lemak, frekuensi konsumsi junk food dan aktivitas fisik (Zalni, Harahap,\& Desfita, 2017). Penelitian menjumpai bahwa banyak remaja putri tidak mengetahui bahwa rentang usia pubertas dimulai dari usia sembilan tahun. Semakin muda usia siswi maka akan semakin belum siap menghadapi menarke karena pada usia yang masih sangat muda mereka belum mendapatkan informasi yang lengkap mengenai menstruasi sehingga menarke akan dianggap sebagai beban oleh anak, dan menyebabkan ketidaksiapan (Luthfia, 2016).

Penelitian ini mengetahui bahwa tingkat kesiapan rata-rata untuk menarche adalah 5,34. Keadaan ini menunjukkan bahwa kesiapan siswi masih kurang dalam menghadapi menarche. Nilainilai kesiapan pada penelitian ini cukup bervariasi ini menunjukkan bahwa respon siswi terhadap menarche berbeda. Remaja dapat berespon positif atau negatif terhadap menstruasi. Santrock (2003), menyatakan reaksi yang sering muncul dalam respon anak perempuan terhadap menarche adalah positif. Menarche dijadikan indeks kedewasaan mereka. Reaksi positif mengindikasikan bahwa anak perempuan yang telah menstruasi diasumsikan telah mampu memiliki anak dan mengalami sesuatu yang membuat mereka menjadi wanita yang lebih dewasa, serta menjadikan mereka lebih mirip dengan teman-temannya yang sudah mengalami menstruasi.

Menstruasi menimbulkan reaksi positif dan negatif bagi setiap remaja putri. Aspek negatif dari menarche yang paling sering dilaporkan oleh anak perempuan adalah kerepotan (membawa pembalut pengganti) dan rasa kotor pada daerah alat kelamin akibat darah menstruasi. Sebagian kecil anak perempuan juga mengindikasikan bahwa menarche melibatkan ketidaknyamanan fisik yang menyebabkan keterbatasan tingkah laku dan menciptakan perubahan emosional. Anak perempuan yang tidak siap menghadapi menarche mengindikasikan perasaan negatif terhadap menstruasi daripada mereka yang lebih siap menghadapi menarche dimulainya siklus menstruasi.

Hasil penelitian sebelumnya mengenai kesiapan menghadapi menarche yaitu penelitian Rindawati (2014), menunjukkan bahwa responden menunjukkan tingkat skor kesiapan yang dapat dikatagorikan pada tingkat sedang.

172 
Sebagian remaja berespon positif mengenai menarche dan sebagian berespon negatif. Tingkat ketidaksiapan remaja dalam menghadapi menarke akan menurun seiring dengan tingkatan usia yaitu bila semakin muda seseorang, maka semakin belum siap untuk menerima peristiwa menstruasi sehingga menarke dapat saja diartikan sebagai peristiwa yang mengejutkan dan berbahaya yang terjadi pada tubuhnya dan sangat penting bagi remaja putri untuk mengetahui bagaimana cara yang tepat dalam merawat organ reproduksinya untuk mencegah terinfeksi virus terkait dengan kanker seviks (Indrawati,2012).

Rindawati (2014), menyatakan bahwa kesiapan seseorang dapat dipengaruhi oleh pengetahuan. Pengetahuan seorang individu tentang menstruasi yang diperoleh baik dari pendidikan formal atau non formal sangat berpengaruh pada kesiapan seseorang. Pengetahuan yang rendah akan secara potensial berpengaruh terhadap perilaku dalam menghadapi menstruasi dan dalam hal ini akan mempengaruhi bagaimana remaja memiliki kesadaran untuk menjaga kebersihan genetalianya. Sejalan dengan ini,

Segala tingkah laku individu adalah hasil dari adanya pengetahuan dan proses berfikir. Individu yang dibekali dengan tingkat pengetahuan tertentu baik pengetahuan yang baik akan cindering memiliki sikap dan tingkah laku yang baik. Demikian pula individu dengan pengetahuan yang kurang cenderung memiliki dorongan untuk bertingkah laku yang kurang, sehingga dapat dikatakan bahwa pengetahuan merupakan stimulus terhadap tingkah laku individu (Notoadmodjo, 2010).

Demikian pula dengan proses seseorang sebelum mengadopsi perilaku baru adalah awareness (kesadaran). Kesadaran berhubungan langsung dengan pengetahuan, oleh karena itu apabila responden memiliki kesadaran yang baik maka respondenpun akan menunjukkan praktik menjaga kebersihan genetalia yang baik pula (Notoatmodjo,2007),

Kesiapan ini akan berpengaruh terhadap perubahan primer pada usia pubertas. Kesiapan menarche mencakup tiga aspek yaitu pemahaman, penghayatan, dan kesediaan (Yusuf,2002). Maka dari itu, informasi dan pemahaman sangat diperlukan sehingga remaja dapat siap menerima menstruasi pertama (menarche). Kesiapan dapat dipengaruhi oleh faktor internal dan eksternal. Faktor internal mencakup kematangan, kecerdasan, keterampilan, kemampuan, dan minat serta motivasi. Selain itu, kedekatan antara anak dan orang tua dengan yang merupakan sumber pengetahuan pertama yang didapatkan oleh seorang anak menuntut peran penting seorang ibu memberikan edukasi atau informasi awal kepada anaknya tentang menstruasi (Gultie et al, 2014).

\section{KESIMPULAN}

Berdasarkan hasil penelitian ini dapat disimpulkan bahwa rata-rata usia remaja awal mengalami menstruasi di SD 2 dalung yaitu pada usia adalah 11 tahun. Responden rerata pada kelas V. Diketahui tingkat kesiapan menstruasi siswi yaitu pada nilai 5,34 yaitu pada katagori kesiapan kurang. Berdasarkan hasil penelitian ini dapat disarankan agar lebih banyak lagi upaya yang dilakukan baik keluarga atau sekolah dalam mempersiapkan siswi menghadapi menarche. Peneltian selanjutnya dapat juga dilanjutkan dengan melakukan modifikasi intervensi yang dapat dilakukan untuk meningkatkan kesiapan remaja menjalani menarche. 


\section{DAFTAR PUSTAKA}

Aprilani, G. (2007). Dukungan Ibu Terhadap Remaja Putri Dalam Membantu Kesiapan Anak Dalam Menghadapi Menarche: Studi Kualitatif Pada Ibu Dari Siswi SD Pedurungan Kidul 07 Semarang. Universitas Diponegoro Semarang

Badan Penelitian Dan Pengembangan Kesehatankementerian Kesehatan RI (2010). Riset Kesehatan Dasar. 2010. Kementerian Kesehatan. Diakses dari http://kesga.kemkes.go.id/images/pedo man/Riskesdas\%202010\%20Nasional. pdf

Behera et al. (2015). Menarche And Menstruation In Rural Adolescent Girls in Maharashtra, India: A qualitative study. Journal of Health Management 17(4) 510-519 Diakses dari:

http://www.unicef.org/adolescence/.

Efendi.F \&Makhfudli, (2009). Keperawatan Kesehatan Komunitas: Teori dan Praktik dalam Keperawatan. Salemba Medika. Jakarta

Fajri A, Khairani M. (2010). Hubungan Antara Komunikasi Ibu-Anak Dengan Kesiapan Menghadapi Menstruasi Pertama (Menarche) Pada Siswi SMP Muhammadiyah Banda Aceh. Semarang: Universitas Diponegoro. Jurnal Psikologi Undip, 10(2), 136

Gultie, T.K.(2014). Practice of Menstrual Hygiene and Associated Factors Among Female Mehalmeda High School Students in Amhara Regional State, Ethiopia.Science Journal of Public Health, 2(3): 189-195

Indrawati, K. 2012. Upaya Meningkatkan Pengetahuan Tentang Kesehatan Organ Reproduksi Siswi Kelas VIII SMPN 10 Surabaya Melalui Metode Tutor Sebaya. E-Jurnal Dinas Pendidikan Kota Surabaya.5:1-11
Kusmiran, Eny. 2011. Kesehatan Reproduksi Remaja dan Wanita. Jakarta : Salemba Medika

Lee, M. H., Kim, S. H., Oh, M., Lee, K. W., \& Park, M. J. (2016). Age At Menarche in Korean Adolescents: Trends And Influencing Factors. Reproductive health, 13(1), 121. doi:10.1186/s12978-016-0240-y

Lutfiyah, I. (2016). Analisis Kesiapan Siswi Sekolah Dasar Dalam Menghadapi Menarche. Jurnal Biometrika dan Kependudukan. Vol. 5, No. 2

Nagar, S. \& Aimol, R. (2010). Knowledge of Adolescent Girls Regarding Menstruation in Tribal Areas of Meghalaya. Journal of kathmandu Medical college, 8(1), 124-128

Notoatmodjo, S. (2010). Metodologi Penelitian Kesehatan. Jakarta: RinekaCipta

Notoatmodjo. S. (2007). Ilmu Perilaku Kesehatan. Jakarta : PT Rineka Cipta.

Rindawati, N., 2014. Gambaran KesiapanDiri Remaja Putri Dalam Menghadapi Menarche di SMPN 1 Ngemplak Boyolali. Tugas Akhir. Sekolah Tinggi Ilmu Kebidanan Kusuma Husada Surakarta.

Santrock (2003). Perkembangan Remaja. Edisi Keenam. Jakarta: Erlangga

Sukarni, I K\& Wahyu, P. (2013). Buku Ajar Keperawatan Maternitas. Yogyakarta: NuhaMedika

UNICEF. (2011). Adolescence An Age of Opportunity. United Natio Children's Found.

Wiknjosastro, H. (2010). Ilmu Kebidanan. Jakarta: Yayasan Birfa Pustaka

Yusuf , A.M. (2002). Pengantar Ilmu Pendidikan. Jakarta : Ghalia Indonesia

Zahroh, F. (2006). Hubungan Antara Dukungan Sosial dengan Kesiapan Menghadapi Menarche pada Anak Asrama di Madrasah Tsanawiyah Mu"alimat Muhammadiyah 
Yogyakarta. STIKES Aisyiyah.

Yogyakarta

Zalni,R.I.,Harahap,Desfita,S.(2017). Usia Menarche Berhubungan dengan Status

Gizi, Konsumsi Makanan, dan Aktibitas Fisik. Jurnal Kesehatan Reproduksi. Doi. 10.22435.kespro.v8i2.6918.153.1 